\title{
Correction to: Molecular characterization and expression analysis of hepc1 and hepc2 in three tilapia species collected from Lake Manzala
}

Karima F. Mahrous ${ }^{*}$, Heba A. M. Abd El - Kader, Dalia M. Mabrouk, Mohamad M. Aboelenin, Noha M. Osman, Wagdy K. B. Khalil and Mohamed Saber Hassanane

\author{
Correction to: Bull Natl Res Cent (2020) 44:36 \\ https://doi.org/10.1186/s42269-020-0278-4
}

After publication of the original article (Mahrous et al. 2020), we were notified that Fig. 1 is incorrect. The corresponding author uploaded the wrong figure by mistake. Below the correct version of Fig 1.

The correct Fig. 1 is below: right column within page 3 and the fourth line in the right column within page 5 should be corrected to $375 \mathrm{bp}$, instead of $273 \mathrm{bp}$.

The corresponding author has confirmed this correction will not make any change to the conclusion of their ori-
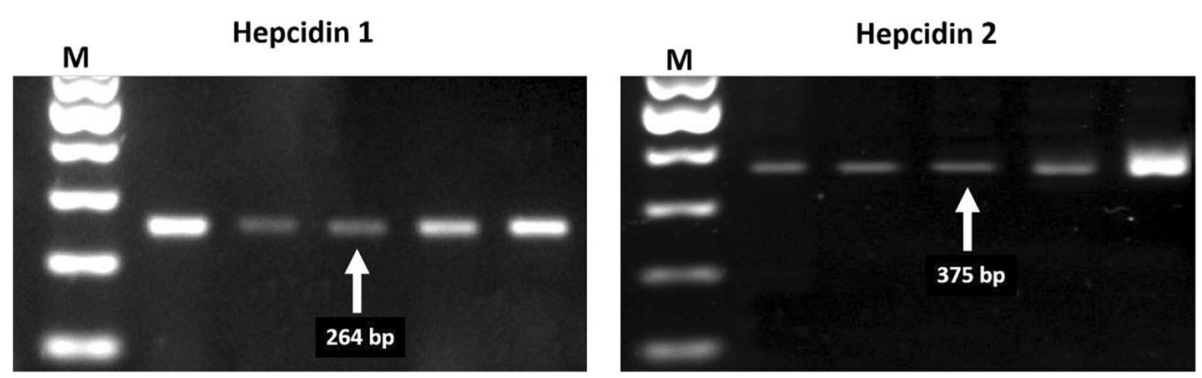

Fig. 1 Agarose gel electrophoresis of hepcidin 1 (264 bp, left panel) and hepcidin 2 (375 bp, right panel)-PCR fragment. M, 100 bp DNA ladder

Furthermore, the hepcidin 2 PCR product in the 3 investigated species is $375 \mathrm{bp}$ as it was indicated in Fig. 6 and GeneBank records with accession numbers MH651359.1, MH651363.1, andMH651367.1. The hepcidin 2 PCR product length in the last line in the

\footnotetext{
*Correspondence: I_fathy@yahoo.com

The original article can be found online at https://doi.org/10.1186/s42269020-0278-4

Cell Biology Department, National Research Centre, 33 El Buhouth St., Dokki, Giza postal code 12622, Egypt
}

\section{Springer Open}

(c) The Author(s). 2020 Open Access This article is licensed under a Creative Commons Attribution 4.0 International License which permits use, sharing, adaptation, distribution and reproduction in any medium or format, as long as you give appropriate credit to the original author(s) and the source, provide a link to the Creative Commons licence, and indicate if changes were made. The images or other third party material in this article are included in the article's Creative Commons licence, unless indicated otherwise in a credit line to the material. If material is not included in the article's Creative Commons licence and your intended use is not permitted by statutory regulation or exceeds the permitted use, you will need to obtain permission directly from the copyright holder. To view a copy of this licence, visit http://creativecommons.org/licenses/by/4.0/.

ginal research. The authors apologize for any inconvenience that this may have caused.

Published online: 16 April 2020

Reference

Mahrous KF et al (2020) Molecular characterization and expression analysis of hepc1 and hepc2 in three tilapia species collected from Lake Manzala. Bull Natl Res Cent 44:36. https://doi.org/10.1186/s42269-020-0278-4 